\title{
34. MICROTEKTITES OF LATE EOCENE AGE FROM THE EASTERN CARIBBEAN SEA
}

\author{
Thomas W. Donnelly, Department of Geology, State University of New York, New York \\ and \\ E.C.T. Chao, U.S. Geological Survey, Washington, D.C.
}

\section{INTRODUCTION}

Tiny glass spherules recovered from the core catcher of Core 31, Site 149 (Venezuelan Basin) are the first identified microtektites from the Deep Sea Drilling Project. Two microtektites, a sphere and a broken spheroidal fragment, both slightly less than 300 microns in size, were found by one of us (TD) on board the ship while examining a washed radiolarian sample for volcanic detritus. Further examination of the radiolarian ooze yielded four microtektites, two stony spheroids, and a peculiar reddish melonseed-shaped particle. A search through material in the uppermost portion of the next lower core yielded no microtektites.

Chemical examination by electron microprobe and optical studies have confirmed identification of the microtektites. Their location and stratigraphic position (Thyrsocyrtis bromia Zone, late Eocene) suggest a correlation with bediasites, which are known from Texas, Georgia, and Cuba, and which have been assigned a tentative late Eocene age.

\section{PHYSICAL AND OPTICAL PROPERTIES}

Sample CC-1 (Plate 1) is a wedge-shaped fragment (broken spheroidal particle) about $157 \times 216 \times 270$ microns. This fragment is brownish and shows schlieren and strain birefringence under the petrographic microscope. The index of refraction of this fragment ranges from $1.5169-1.5204$ by interference microscopy, with the bulk of the glass fragment near 1.5197. Lechatelierite inclusions are present; vesicles and crystalline inclusions are absent.

Sample CC-2 (Plate 1) is a small, nearly perfect gray sphere with a diameter of 175 to 178 microns. It has an index of refraction of 1.5287. The deflection of the interference fringes shows a thin rim of different index, probably resulting from diagenetic changes (hydration). The spheroid shows strain birefringence and schlieren.

Sample CC-3 (Plate 1) is a large oblate brownish spheroid, with an intermediate diameter of 293.3 microns. The bulk of this glass has an index of refraction of 1.5151. The fragment shows schlieren and strain birefringence and contains lechatelierite.

Sample CC-12 is an irregular brownish fragment with an index of refraction of 1.5281 .

Sample CC-5 is the larger of two small opaque probably partly divitrified grayish-brown spheres and is approximately 200 microns in diameter. It exhibits a very fine color mottling.

The red melonseed-shaped particle is $28.3 \times 103.6 \times$ 137.1 microns and has a high index of refraction (1.780). It is isotropic and has a distinctive rim possibly due to increased thickness or higher index of refraction.
Also found with these fragments in this dominantly radiolarian sample are fish teeth, abundant fresh glass shards, several plagioclase and clinopyroxene crystals, and one orthopyroxene crystal. The orthopyroxene appears to belong to a general eastern Caribbean mid-Tertiary calcalkaline volcanic episode.

\section{CHEMISTRY OF THE MICROTEKTITES}

Electron microprobe analyses of the four microtektites, one opaque spheroid, and five of the co-occurring glass shards, are shown in Table 1. Tektites are distinguished from igneous glasses of the same silica content principally by their relatively high $\mathrm{CaO}, \mathrm{MgO}$, and $\mathrm{FeO}$, and by their low $\mathrm{Na}_{2} \mathrm{O}$ and $\mathrm{K}_{2} \mathrm{O}$. These microtektites have distinctively high $\mathrm{FeO}$, less distinctively high $\mathrm{MgO}$, undistinctive $\mathrm{CaO}$, somewhat low $\mathrm{Na}_{2} \mathrm{O}$, and somewhat high $\mathrm{K}_{2} \mathrm{O}$. They are quite unlike the co-occurring glass shards.

Among known tektite groups (Chao, 1963), the Caribbean microtektites are closest to the bediasites, especially in their high $\mathrm{FeO} / \mathrm{MgO}$ ratios and generally low content of $\mathrm{CaO}$ and $\mathrm{MgO}$. Their alkalies, however, are somewhat anomalous in showing a high $\mathrm{K}_{2} \mathrm{O} / \mathrm{Na}_{2} \mathrm{O}$ ratio compared with all other tektites. With the possible exception of the moldavites.

The chemical relationship between microtektites and tektites of a single strewn field has been most thoroughly explored by Cassidy et al. (1969) for the Australasian strewn field. Their results show that microtektites range to considerably lower silica values than cooccurring tektites, that for the two groups the other chemical components generally show similar trends with silica, and that there are some microtektites with quite different chemical trends (their "bottle-green microtektites"). In a further detailed study of the Australasian tektites, Chapman and Scheiber (1969) showed that there are several distinctive chemical subgroups of tektites from a single strewn field. Figure 1 shows the relationship between the Site 149 microtektites and the trends for bediasite compositions as reported by Chao (1963). The present samples, although exhibiting considerable scatter, show a similarity to bediasites, including low $\mathrm{MgO}$ and $\mathrm{CaO}$, but they have distinctively higher $\mathrm{K}_{2} \mathrm{O}$. Diagenetic addition of $\mathrm{K}$ seems unlikely; the Australasian microtektites (Cassidy, et al., 1969) show no apparent uptake of this element, although it should be noted that they are about fifty times younger than the Site 149 samples.

We conclude that, on chemical grounds, the Site 149 samples are closest to bediasites, but are not necessarily identical. 
TABLE 1

Chemical Composition of the Caribbean Deep-Sea Glass Particles in Weight Per Cent ${ }^{\mathrm{a}}$

\begin{tabular}{|c|c|c|c|c|c|c|c|c|c|c|c|c|c|}
\hline & \multicolumn{7}{|c|}{ Microtektites } & \multirow{2}{*}{$\begin{array}{c}\begin{array}{c}\text { Opaque } \\
\text { Spheroid }\end{array} \\
c c-5\end{array}$} & \multicolumn{5}{|c|}{ Glass Shards } \\
\hline & $\mathrm{ccl} 1-1$ & $\mathrm{ccl}-2$ & cc1-4 & cc-2 & $\operatorname{cc} 3-1$ & $\operatorname{cc} 3-2$ & $z c-12-2$ & & cc-7 & cc-11 & cc-13 & $\mathrm{cc}-14$ & cc-9 \\
\hline $\mathrm{SiO}_{2}$ & 75.10 & 70.10 & 70.20 & 61.90 & 60.60 & 65.90 & 71.50 & 58.80 & 77.30 & 76.30 & 74.80 & 75.50 & 77.00 \\
\hline $\mathrm{TiO}_{2}$ & 0.87 & 0.73 & 0.73 & 0.98 & 0.96 & 0.75 & 0.64 & 0.28 & 0.33 & 0.39 & 0.31 & 0.38 & 0.34 \\
\hline $\mathrm{Al}_{2} \mathrm{O}_{3}$ & 16.10 & 15.10 & 14.10 & 18.30 & 17.10 & 14.60 & 15.20 & 6.10 & 13.20 & 12.60 & 13.00 & 13.90 & 13.50 \\
\hline $\mathrm{FeO}^{\mathrm{b}}$ & 4.80 & 4.00 & 4.40 & 6.60 & 6.20 & 4.90 & 4.90 & 10.20 & 2.70 & 2.90 & 2.90 & 3.10 & 2.60 \\
\hline $\mathrm{MgO}$ & 1.71 & 1.28 & 1.27 & 3.10 & 2.70 & 2.00 & 10.20 & 0.38 & 0.31 & 0.26 & 0.48 & 0.48 & 0.32 \\
\hline $\mathrm{CaO}$ & 1.67 & 1.21 & 1.46 & 2.50 & 2.10 & 1.54 & 3.60 & 13.90 & 1.97 & 2.00 & 1.88 & 2.30 & 1.98 \\
\hline $\mathrm{Na}_{2} \mathrm{O}$ & 1.13 & 0.90 & 0.96 & 1.26 & 1.13 & 0.88 & 1.89 & 0.57 & 1.82 & 1.51 & 1.52 & 1.34 & 1.52 \\
\hline $\mathrm{K}_{2} \mathrm{O}$ & 2.80 & 3.10 & 3.00 & 3.20 & 3.00 & 3.40 & 1.11 & 1.53 & 1.42 & 1.11 & 1.18 & 0.94 & 1.26 \\
\hline $\mathrm{MnO}$ & 0.09 & 0.06 & 0.07 & 0.10 & 0.08 & 0.07 & 0.11 & 0.12 & 0.07 & 0.07 & 0.08 & 0.10 & 0.07 \\
\hline Total & 104.00 & 96.00 & 96.00 & 98.00 & 94.00 & 94.00 & 100.00 & 102.00 & 99.00 & 97.00 & 96.00 & 98.00 & 99.00 \\
\hline $\mathrm{N}$ & \multicolumn{3}{|c|}{ Range $1.5169-1.5204$} & 1.5287 & \multicolumn{2}{|c|}{1.5151} & 1.5281 & n.d. & 1.5131 & 1.5121 & 1.5112 & 1.5121 & 1.5121 \\
\hline
\end{tabular}

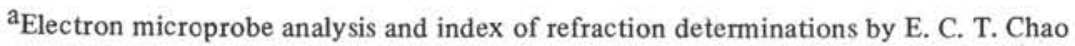

${ }^{\mathrm{b}_{\mathrm{T}}}$ tal iron as $\mathrm{FeO}$

n.d. - Not determined

\section{CHEMISTRY OF THE OTHER FRAGMENTS}

A reconnaissance microprobe analysis of the red melonseed-shaped particle showed high $\mathrm{Fe}$ and little or no $\mathrm{Si}, \mathrm{Al}$, or Ti. Evidently, it is dominantly a hydrated iron oxide or oxysalt. It could represent a highly altered extraterrestrial fragment, but it could easily be of terrestrial origin, although nothing similar was found in other samples.

The opaque spheroid (CC-5) has a chemical composition quite unlike either any known extraterrestrial or terrestrial igneous material. Especially notable, considering the silica content of nearly 59 per cent, are the low $\mathrm{Al}_{2} \mathrm{O}_{3}$ and alkalies and the high $\mathrm{FeO}, \mathrm{MgO}$, and $\mathrm{CaO}$. We conclude that the particle, and doubtless its unanalyzed companion, are probably extraterrestrial, but, if diagenetically unaltered, represent a hitherto unrecognized class of meteoritic materials.

\section{AGE}

The stratigraphic position of the sample is within the Thyrsocyrtis bromia Zone of latest Eocene age, although the position within that zone is not known. According to Barnes (1963), the stratigraphic position of the Texas bediasites is probably within the Jackson Group (late Eocene), although he reported no tektites which were found in place. This coincidence in stratigraphic position suggests that the Site 149 fragments could belong to the bediasite strewn field.

Table 2 shows radiometric ages for bediasites and for glauconite occurring in stratigraphic positions close to the Eocene-Oligocene boundary. The bediasites appear to be younger than the estimated age for this boundary (Berggren, in press) by about 3 million years. Glauconite $\mathrm{K}$-Ar ages, however, are inherently suspect, and they could conceivably be biased in one direction or another. The tektite radiometric ages have the advantage that tektites are quite argon retentive (Zähringer, 1963a), but the disadvantages that potassium is generally low, the ages are young, and the amount or isotopic character of any original argon is unknown. Fission-track ages (Garlick, et al., 1971) of bediasites, however, are indistinguishable from K-Ar ages, suggesting the validity of this method.

We suggest that the reported ages of bediasites and the estimated age for the Eocene-Oligocene boundary are sufficiently close to support the idea that the latter age may have to be modified by a million years or more.

\section{CONCLUSIONS}

The glassy fragments from Site 149 are microtektites, and the opaque spheroid is probably also extraterrestrial. The chemical composition of the microtektites are closest to bediasites among known tektites, but could represent a new strewn field. The location (Figure 2) and stratigraphic position of the occurrence support the idea that these samples belong to the bediasite strewn field. Further refinement of radiometric ages for the Paleogene time scale will be necessary in order to support or disprove the contention that these fragments might belong to the bediasite strewn field.

\section{ACKNOWLEDGMENTS}

We are very grateful to W.A. Berggren for comments and preprints regarding the question of the age of the EoceneOligocene boundary. Professor B. Glass provided further information on bediasite occurrences. 

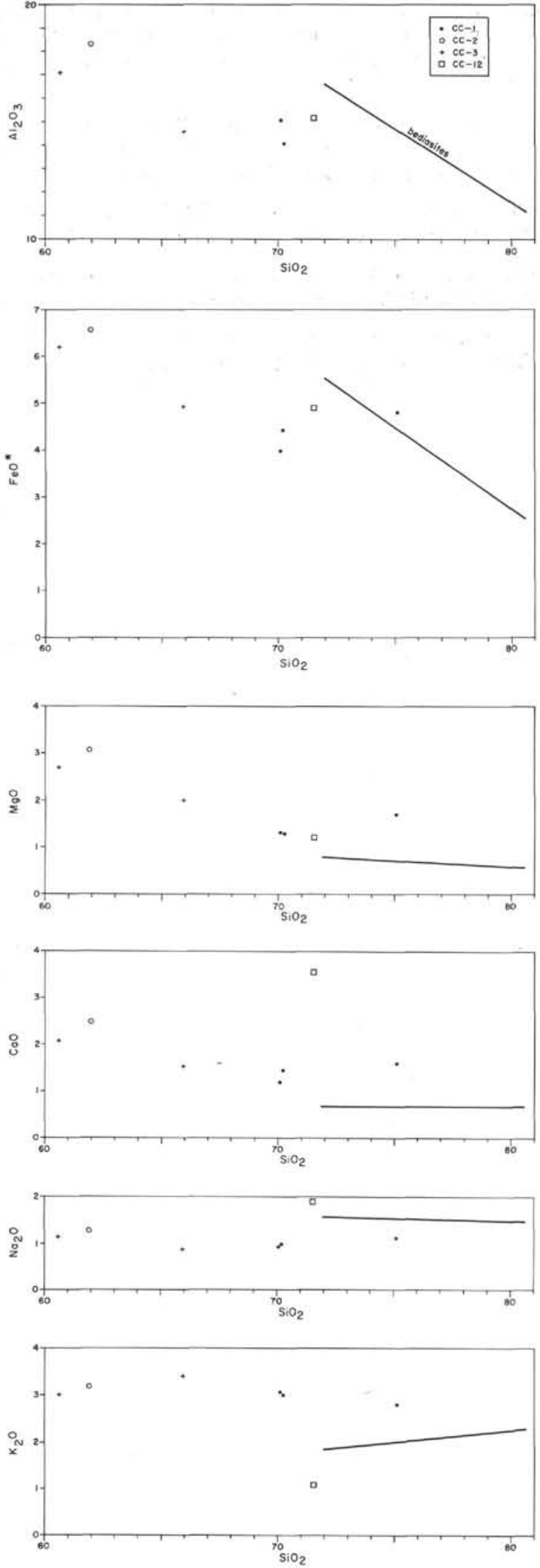

Figure 1. Chemical trends of bediasites (Chao, 1963) compared with analyzed microtektites from Site 149.

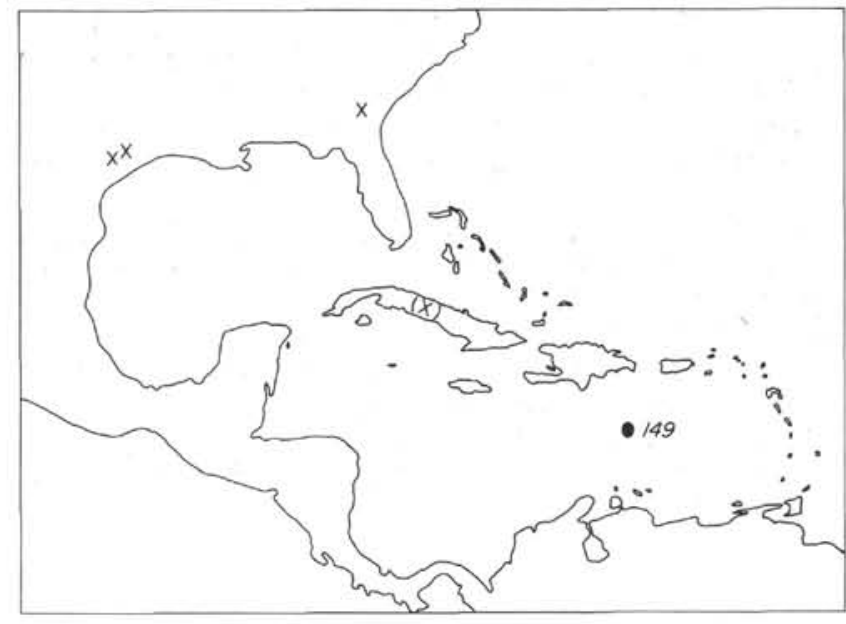

Figure 2. Map of Middle America, showing known bediasite occurrences ( $X$ 's) in relation to Site 149 . Note that the exact location of the Cuban tektite is unknown.

TABLE 2

Radiometric Ages of Bediasites and of Selected Glauconites Especially Close to the Eocene-Oligocene Boundary

\begin{tabular}{|c|c|c|c|}
\hline Material & Method & Age & Reference \\
\hline Bediasites & K-AR & $34.2 \pm 0.8$ & Zahringer (1963b) \\
\hline Bediasites & F-T & $34.5 \pm 1.5$ & $\begin{array}{l}\text { Fleischer and Price } \\
\text { (1964) }\end{array}$ \\
\hline Georgia tektite & $\mathrm{K}-\mathrm{Ar}$ & $34.5 \pm 1.4$ & Zahringer (1963b) \\
\hline $\begin{array}{l}\text { Martha's Vineyard } \\
\text { tektite }\end{array}$ & $\mathrm{K}-\mathrm{Ar}$ & $33.7 \pm 2.2$ & Zahringer (1963b) \\
\hline $\begin{array}{l}\text { Martha's Vineyard } \\
\text { tektite }\end{array}$ & F-T & $35.5 \pm 8.3$ & $\begin{array}{l}\text { Fleischer, et al. } \\
\text { (1965) }\end{array}$ \\
\hline Cuban tektite & F-T & $35.6 \pm 2.8$ & Garlick et al. (1971) \\
\hline $\begin{array}{l}\text { Glauconite, Barton } \\
\text { Beds, (late } \\
\text { Eocene), } \\
\text { England }\end{array}$ & $\mathrm{K}-\mathrm{Ar}$ & $42.0-43.6 \pm 2$ & Berggren (in press) ${ }^{\mathrm{a}}$ \\
\hline $\begin{array}{l}\text { Glauconite, Argile } \\
\text { d'Assee (late } \\
\text { Eocene), } \\
\text { France }\end{array}$ & $\mathrm{K}-\mathrm{Ar}$ & $41.8 \pm 3$ & Berggren (in press) ${ }^{\mathrm{a}}$ \\
\hline $\begin{array}{l}\text { Glauconite, Sands } \\
\text { of Neerrepen } \\
\text { (latest Eocene } \\
\text { or early } \\
\text { Oligocene), } \\
\text { Belgium }\end{array}$ & $\mathrm{K}-\mathrm{Ar}$ & $37.5 \pm 2$ & Berggren (in press) ${ }^{\mathrm{a}}$ \\
\hline
\end{tabular}

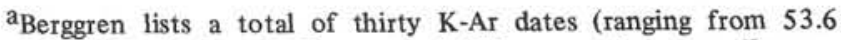
to $28.8 \mathrm{my}$ ) for the Eocene and Oligocene of western Europe, of which these three are closest to the boundary between the two epochs. 


\section{REFERENCES}

Barnes, V. E., 1963. Tektite strewn-fields. In Tektites, J. A. O'Keefe (Ed.), Univ. of Chicago Press. 25.

Berggren, W. A., (in press). A Cenozoic time-scale-some implications for regional geology and paleobiogeography. Lethaia.

Cassidy, W. A., Glass, B. and Heezen, B. C., 1969. Physical and chemical properties of Australasian microtektites. Geophys. Res. 74, 1008.

Chao, E. C. T., 1963. The petrographic and chemical characteristics of tektites. In Tektites, J. A. O'Keefe (Ed.) Univ. of Chicago Press. 51.

Chapman, D. R. and Scheiber, L. C., 1969. Chemical Investigation of Australasian tektites. J. Geophys. Res. 74, 6737 .
Fleischer, R. L. and Price, P. B., 1964. Fission track evidence for the simultaneous origin of tektites and other natural glasses. Geochim. Cosmochim. Acta. 28, 755.

Fleischer, R. L., Price, P. B. and Walker, R. M., 2965. On the simultaneous origin of tektites and other natural glasses. Geochim. Cosmochim. Acta. 29, 161.

Garlick, G. N., Naeser, G. W., and O'Neil, J. R., 1971. A Cuban tektite. Geochim. Cosmochim. Acta. 35, 731.

Zähringer, J., 1963a. Isotopes in tektites. In Tektites, J. A. O'Keefe (Ed.) Univ. of Chicago Press. 137.

Zähringer, J., 1963b. K-Ar measurements of tektites. Radioactive Dating, IAEA (Vienna) 289. 



\section{PLATE 1}

Photomicrographs in Transmitted and Reflected Light, and Interference Photomicrographs, or Microtektite Samples CC-1, CC-2, and CC-3.

The three reflection photomicrographs in the lower right show the microtektites mounted for optical examination.

The transmission photomicrographs (center) show schlieren (especially CC-3) and a distinct lechatelierite inclusion (arrow) in CC-1.

In the interference photomicrographs the deviations of the fringe lines show deviations in the optical path distance, which is a function of index of refraction and grain geometry. Abrupt shifts of the fringes in CC-1 show both inhomogeneities in index of refraction (higher index shifts fringe to right) and a prominent horizontal fracture below the center. "Islands" surrounded by one or more fringes show inclusions of low-index lechatelierite. The interference photomicrograph of CC-3 shows pronounced index of refraction inhomogeneities in a nearly perfect spheroid. The interference photomicrograph of CC-2 shows a rim of lower index surrounding higher index material (diagenetic effect?). 
PLATE 1
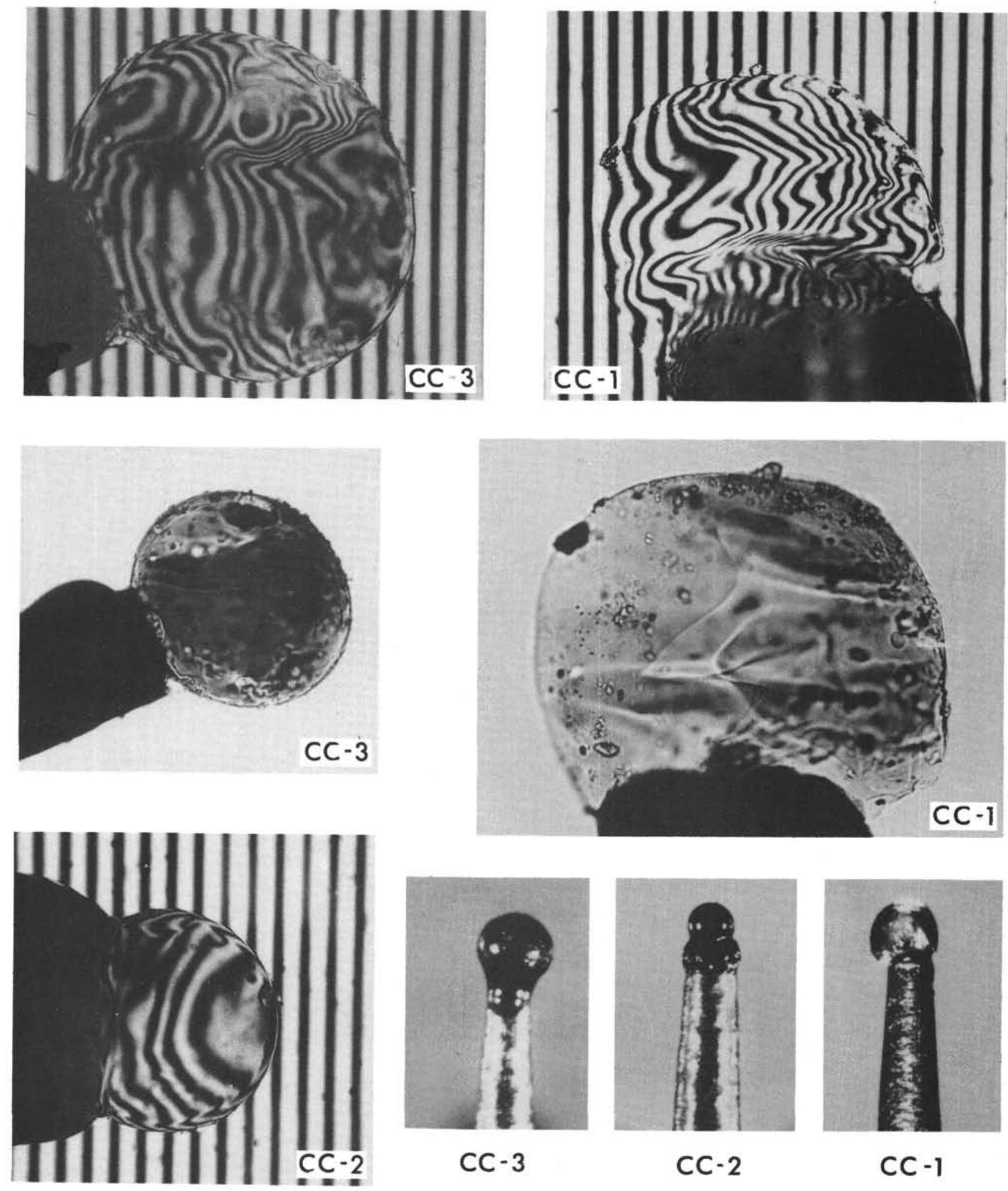

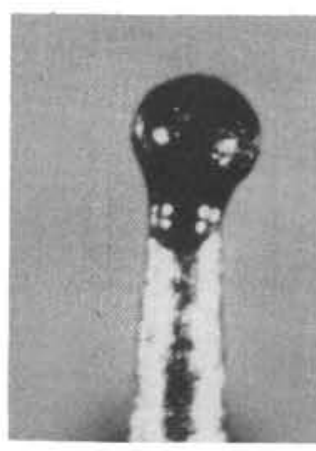

$\mathrm{CC}-3$

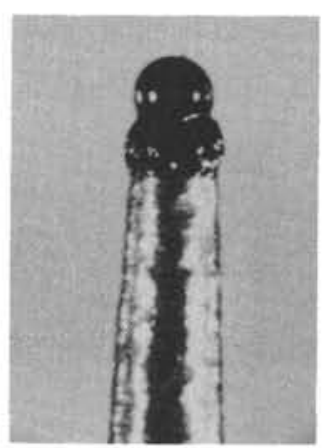

$\mathrm{CC}-2$

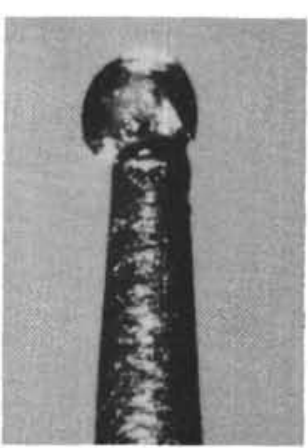

$\mathrm{CC}-1$ 